\title{
Dwujęzyczność w twórczości Jana Kochanowskiego
}

\section{Agnieszka Kwiatkowska}

W całej Europie od wczesnego średniowiecza aż po początek XVI wieku literatura łacińska i polska rozwijały się niemal niezależnie od siebie, a ich wzajemne oddziaływanie dotyczyło niewielu aspektów. Domeną liturgii i utworów powiązanych z ceremoniałem religijnym bardzo długo pozostawała łacina. Dopiero w XIV wieku zaczęły powstawać po polsku pierwsze utwory liryczne o tematyce religijnej (ich szereg otwiera Bogurodzica, datowana już na koniec XIII wieku) i najstarsze tomy polskojęzycznych kazań (m.in. Kazania świętokrzyskie). Hagiografia i historiografia - jako formy wymagające bardziej precyzyjnego i operującego słownictwem abstrakcyjnym języka - realizowane były niemal wyłącznie po łacinie jeszcze w późnym średniowieczu. Wielu twórców posiadło znajomość obu języków, w każdym z nich realizując inne konwencje i tematy. Tak czynił na przykład Władysław z Gielniowa, autor między innymi polskojęzycznych abecedariuszy i łacińskiego - również abecedariuszowego, ale pisanego heksametrem - poradnika dla kapłanów. Rozwój wczesnorenesansowej poezji nowołacińskiej, służącej intelektualnej rozrywce, w żaden sposób nie podważył rozłączności literatury powstającej w obu językach. Łacińska nadal pozostawała domeną humanistów, skupionych na retoryce i poezji, polska - stała się żywiołem popularnych narracji i obfitowała, z jednej strony, w utwory nawiązujące do średniowiecza, z drugiej - w wypowiedzi utrzymane w duchu reformacji.

Wykształcony Staropolanin przełączał się z jednego kodu na drugi, zależnie od sytuacji kulturowej, w której się znalazł i adekwatnie do podejmowanej właśnie konwencji literackiej. W sposób typowy dla zjawiska dwujęzyczności kompetencje użytkownika pozostawały ściśle sprofilowane, każdy z języków miał inną specjalizację i obsługiwał przypisaną sobie sferę działalności życiowej (czy - w tym przypadku - działalności twórczej) pisarza dwujęzycznego $^{1}$. Interferencja - szczególna gra oddziałujących na siebie systemów językowych - polegała wówczas przede wszystkim na wpływie łaciny na polszczyznę (m.in. w dziedzinie składni), na-

\footnotetext{
${ }^{1}$ E. Kraskowska, Dwujęzyczność a problemy przekładu, [w:] Miejsca wspólne, red. E. Balcerzan, S. Wysłouch, Warszawa 1985, s. 195.
} 
tomiast w odwrotnym kierunku prawie nie zachodziła. W łacińskich utworach średniowiecznych niemal nie widać wpływów polszczyzny, realizują one powszechnie przyjęte w Europie konwencje, w niewielkim stopniu dopuszczając do głosu interferencję kulturową czy językową ${ }^{2}$. W poezji humanistycznej wczesnego renesansu nowołacińskie teksty pozostają osadzone w polskiej kulturze, co znacząco wpłynęło na opis lokalnych elementów, ale nadal jedynym przejawem nakładania się dwóch systemów językowych były nazwy własne, wprowadzane do wielu utworów Andrzeja Krzyckiego czy Konrada Celtisa. Jan Kochanowski zdołał połączyć oba nurty i w polszczyźnie dać wyraz myśli humanistycznej, dotąd w pełni werbalizowanej wyłącznie po łacinie ${ }^{3}$.

Poeta dorastał w rodzinie szlacheckiej, ceniącej wykształcenie i wrażliwej na kulturę słowa. Jego matka - Anna z rodu Odrowążów - została wspomniana w Dworzaninie polskim Łukasza Górnickiego jako osoba stateczna i obdarzona poczuciem humoru („stateczna pani i bardzo trefna"). Ojciec poety - Piotr Kochanowski - planował posłać synów na studia, choć i bez wykształcenia zapewne mógłby im zapewnić dostatnie życie. Komornik radomski i sędzia sandomierski wytrwale gromadził doczesne dobra, pomnażane dzięki mariażom, korzystnym transakcjom i wygrywanym procesom ${ }^{4}$. Spośród licznego rodzeństwa Mikołaj tłumaczył Plutarcha i był autorem Rotuł, Andrzej przekładał Eneidę, jedna z sióstr stała się „inspiratorką i niemal współautorką" Dziewostęba dworskiego ${ }^{5}$. Talentu nie zabrakło i w następnym pokoleniu Kochanowskich - bratanek Jana, Piotr, był wybitnym poetą i tłumaczem Jeruzalem wyzwolonej Torquatta Tassa.

Zanim Jan Kochanowski trafił na uniwersytet, z pewnością opanował podstawy gramatyki łacińskiej oraz posiadł umiejętność czytania i pisania. Nie wiemy, czy wraz z braćmi kształcił się pod opieką domowego nauczyciela, czy korzystał ze szkoły prowadzonej przez benedyktynów sieciechowskich, musiał jednak już wówczas podejmować pierwsze próby lektury pisarzy rzymskich ${ }^{6}$. Bez wątpienia zetknął się również z chłopsko-szlacheckim folklorem, z polskojęzyczną literaturą ustną, w XVI wieku harmonijnie współistniejącą z książką drukowaną. Janina Abramowska tak pisze o młodzieńczych doświadczeniach literackich Kochanowskiego, wskazując utwory, które mógł poznać za młodu:

Obok „babich baśni” mogły to być wątki pochodzenia literackiego, z Historii rzymskich, Poncjana, Żywota Ezopa Fryga, Sowiźrzała. Wszystkie te utwory były już wydane w wersji polskiej, musiano je kupować, pożyczać, a pewnie i opowiadać zapamiętane fabuły. [...] Możliwe więc, że już jako chłopiec Kochanowski poznał z lektury lub ze słyszenia opowieści błazeńskie, a na pewno nie były mu obce sąsiedzkie anegdoty i tłuste facecje. W ten sposób wcześnie znalazł się w kręgu kultury ludycznej, której znajomość, pogłębiona potem w krakowskich gospodach i włoskich tawernach, odegra tak ważną rolę w jego twórczości?

\footnotetext{
2 Por. tamże, s. 185.

${ }^{3}$ J. Abramowska, Kochanowski, Poznań 1994, s. 16.

4 Tamże, s. 9. J. Pelc podaje, że Piotr Kochanowski był to „średniozamożny ziemianin, zapobiegliwy o swe interesy”. J. Pelc, Jan Kochanowski poeta renesansu, Warszawa 1988, s. 23.

${ }^{5}$ Wspomina o tym Abramowska, Kochanowski, dz. cyt., s. 10.

${ }^{6}$ Tamże, s. 12.

${ }^{7}$ Tamże.
} 
W krakowskiej Akademii, która wówczas miała już za sobą lata świetności, Kochanowski pogłębił znajomość języka i kultury łacińskiej - uczestniczył w wykładach poświęconych traktatom Cycerona, poznał dzieła Wergiliusza i Horacego, zyskał dostęp do nowości wydawniczych z zakresu poezji nowołacińskiej, rozbudził w sobie chęć dalszego studiowania ${ }^{8}$. W Padwie wybrał wydział humanistyczny (universitas artistorium), odrzucając prawo i medycynę. Nie zdobywał stopni naukowych, skoncentrował się na poszerzaniu własnych horyzontów i pogłębianiu erudycji, świadom wymagań, jakie epoka stawiała twórcom literatury, dążąc do zrealizowania wzoru poetae docti. O jego ówczesnych lekturach pisze Abramowska:

Oczytanie Kochanowskiego w literaturze antycznej obejmowało przede wszystkim pisarzy rzymskich: Cicerona, Wergiliusza, Senekę, Owidiusza, Lukrecjusza, a nade wszystko wielkich liryków: Horacego, Proprecjusza, Katulla. Literaturę grecką znał chyba raczej z przekładów łacińskich, choć język grecki nie był mu obcy, o czym świadczą późniejsze prace translatorskie (Homer, Antologia grecka, Eurypides, uzupełnienie Cycerońskiego przekładu Fenomenów Aratosa). Czytał też na pewno humanistów piszących po łacinie, jak Hieronim Vida, którego heroikomiczny poemacik Scacchia ludus parafrazował potem w Szachach ${ }^{9}$.

Bez wątpienia w czasie studiów padewskich opanował też język włoski i poznał liryki Petrarki. Hołd, jaki oddał poezjom pisanym na cześć Laury w dwóch łacińskich epigramatach, uzmysławia, jak cenił Kochanowski rozwój literatur narodowych. W renesansowej Europie Petrarka zasłynął przede wszystkim jako autor pism łacińskich, które polski poeta znał doskonale, ale mimo to w nagrobnych epigramatach zdecydował się uwiecznić pisane po włosku Canzoniere $^{10}$.

Następujący w Europie rozwój literatur narodowych musiał nasunąć Kochanowskiemu myśl o wprowadzeniu elementów zaczerpniętych z klasycznej starożytności do utworów polskojęzycznych. Zabieg taki miałby podnieść literaturę polską do rangi greckiej i rzymskiej, wzbogacić polszczyznę i rozwinąć jej możliwości. Zasada imitatio - naśladowania antyku - była fundamentalna dla ówczesnej kultury i doskonale uzupełniała postulaty mimesis. Przypomina o tym Ludwika Szczerbicka-Ślęk:

Jednym ze sposobów odzyskiwania antyku, obok poszukiwania zabytków, ich gromadzenia, konserwowania, badania, a w przypadku literatury - wydawania drukiem, którego wynalazek był wielkim sprzymierzeńcem renesansowych dążeń - stało się naśladowanie literatury stworzonej przez starożytnych mistrzów - imitatio. Filozoficzne podłoże naśladownictwa stanowiła wypracowana przez Platona i Arystotelesa teoria mimesis, zgodnie z którą sztuka bierze się z naśladowania natury (obaj przy tym różnie definiowali naturę i rezultaty jej naśladowania). W renesansie przez naturę rozumieć zaczęto świat stworzony przez antycznych poetów i antyk stał się „drugą naturą”. Zauważono także, że w efekcie podobnego postępowania niegdyś Rzymianie, naśladując greckich poprzedników, stworzyli wielką sztukę ${ }^{11}$.

\footnotetext{
8 Tamże, s. 15.

9 Tamże, s. 21.

${ }^{10} \mathrm{~J}$. Pelc, Jan Kochanowski poeta renesansu, dz. cyt., s. 35.

${ }^{11}$ L. Szczerbicka-Ślęk, Wstęp, [w:] J. Kochanowski, Pieśni, Wrocław 1998, s. LVII.
} 
Realizując te zasady, Kochanowski - jak pisał Janusz Pelc - dążył do podjęcia roli

wielkiego i uznanego, doskonałego poety, nowego Orfeusza, twórcy znakomitych, dorównujących arcydziełom starożytności dzieł literatury narodowej komponowanych w języku ojczystym $^{12}$.

Jednym ze środków służących osiągnięciu tego celu stało się tłumaczenie i parafrazowanie rzymskiej liryki. Przekłady utworów Horacego - zgodnie z konwencją epoki opublikowane w zbiorze Pieśni Kochanowskiego bez wskazania oryginału - nie służyły pokonaniu bariery komunikacyjnej czy przyswojeniu dokonań literatury rzymskiej polskiej kulturze. Potencjalni odbiorcy tych tłumaczeń, ludzie wykształceni i biegle władający łaciną, z pewnością znali pieśni Horacego - fundamentalne utwory europejskiego klasycyzmu. Poeta, parafrazując antycznego mistrza, ćwiczył polską frazę i sprawdzał możliwości ojczystego języka, aby wprowadzić rodzimą poezję na wyżyny literackiego parnasu. Nierzadko dostosowywał tłumaczone utwory do realiów, w których żył i do swojej biografii. Niekiedy zmieniał ich wymowę, dopasowując przesłanie Horacego do swoich idei. Zawsze szukał odważnych rozwiązań translatorskich i nie bał się tłumaczyć nawet tego, co z uwagi na różnice kulturowe wydawało się nieprzekładalne.

Do najbardziej znanych parafraz poezji Horacego należą dwa utwory Kochanowskiego: Pieśn XXIV z Ksiąg wtórych (o inc. „Niezwykłym i nie leda piórem opatrzony...”) oraz fragment Pieśni świętojańskiej o Sobótce ${ }^{13}$. W pierwszej z nich, głoszącej apoteozę poety i podejmującej motyw non omnis moriar, wybitny tłumacz zastąpił nazwy plemion żyjących poza obszarem rzymskiego imperium (Getulów, Kolchów), którymi posłużył się Horacy, nazwami współczesnych narodów, a zwrot do Mecenasa zastąpił przywołaniem Myszkowskiego. Fragment ten odbiega od podniosłej stylistyki całego utworu, a personalna wzmianka o Myszkowskim ma charakter poufały i prywatny ${ }^{14}$. Z kolei sobótkowa pieśń Panny XII to dość przewrotne tłumaczenie Epodu II Horacego (o inc. „Beatus ille qui procul negotiis...”). Pochwała wsi w tekście oryginalnym i w przekładzie jest niemal identyczna, obaj poeci wymieniają te same zalety życia wiejskiego i opisują je w podobny sposób. Wiersz Horacego kończy jednak ironiczna pointa, zupełnie zmieniająca wymowę utworu, którą Kochanowski całkowicie pominął. „Ja” lirycznym rzymskiego epodu nie jest wieśniaczka, szczerze wychwalająca uroki sielskiego bytowania, ale lichwiarz Alfius, wyjeżdżający z miasta wyłącznie w czasie zastoju w interesach, gotów porzucić spokój prowincji, gdy tylko ujrzy nadzieję rychłych zysków ${ }^{15}$.

Jedną z najbardziej kunsztownych parafraz pozostaje jednak Pieśn III z Ksiq̨g pierwszych (o inc. „Dzbanie mój pisany...”) - tłumaczenie słynnej ody Horacego O nata mecum consule Manlio... Piotr Wilczek określił to osiągnięcie jako

${ }^{12} \mathrm{~J}$. Pelc, Jan Kochanowski poeta renesansu, dz. cyt., s. 38.

${ }^{13}$ Używam wymiennie terminów „przekład” i „parafraza”, ponieważ w przypadku omawianych utworów granica między tymi kategoriami pozostaje zatarta.

${ }^{14}$ L. Szczerbicka-Ślęk, Wstęp, dz. cyt., s. LVIII.

${ }^{15}$ Końcowe wersy epodu Horacego brzmią następująco w tłumaczeniu Józefa Birkenmajera: „Tak mówił lichwiarz Alfius. Już mu pachnie wieś. / Lecz przyszły Idy, spłaty czas! / Więc wszystek grosz z dłużników złupił, aby gdzieś / Znów go lokować jeszcze raz". 
przekład utworu nieprzekładalnego z powodu zbyt głębokich różnic kulturowych. Zestaw znaków kulturowych uobecnionych w pieśni Horacego [...] jest tak głęboko i wyłącznie zakorzeniony w mitologii, poetyce, historii i obyczajowości starożytnych Rzymian, że wszystkie próby przekładu tej pieśni podejmowane w XIX i XX wieku były kolejnymi świadectwami klęski wytrawnych nieraz tłumaczy ${ }^{16}$.

Kochanowski zrezygnował z żartobliwych aluzji do hymnu na cześć Bachusa, pominął nawiązania mitologiczne, Katona miłującego mero zastąpił filozofami, którzy nie stronią od wina, w miejsce wspomnianego personalnie przyjaciela Horacego przywołał gości. Gliniany, glazurowany i zdobiony dzban o bliżej nie sprecyzowanej zawartości zajął miejsce rzymskiej amfory, wypełnionej massyckim winem. Mimo tak daleko idących zmian, efektem pracy czarnoleskiego poety jest dobry wiersz, wprowadzający w krwiobieg polskiej literatury motywy horacjańskie.

Doskonalenie rodzimego języka poetyckiego nie wykluczało jednak pisania liryków po łacinie ani nie determinowało dokonywania radykalnych wyborów języka, który miałby dominować w liryce Kochanowskiego. Abramowska, opisując dwujęzyczny charakter jego dzieł, zwróciła uwagę na niezdeterminowane chronologicznie zaangażowanie poety w oba rodzaje twórczości:

Tworzenie humanistycznej poezji narodowej poeta łączył przez całe życie z pisaniem wierszy łacińskich, niejednokrotnie tworząc paralelne cykle (foricoenia i fraszki), opracowując w obu językach swoje ulubione tematy [...]. Byłoby błędem zarówno upatrywanie w tym niekonsekwencji, jak poszukiwanie jakiejś linii rozwojowej, która prowadziłaby od łaciny ku polszczyźnie. Twórczość polska i łacińska są nie tylko niesprzeczne, ale stanowią realizację tego samego programu literackiego, który stanowi syntezę dążeń pierwszych humanistów polsko-łacińskich i obrońców języka polskiego $^{17}$.

Twórczość łacińska Kochanowskiego - poza kilkoma rozproszonymi utworami - obejmuje trzy zbiory: Lyricorum libellus (wyd. w Krakowie 1580), Elegiarum libri IV (Kraków 1584) oraz Foricoenia sive Epigrammatum libellus (Kraków 1584). Najwcześniejsze utwory łacińskie wielokrotnie przerabiane i przeredagowywane - między innymi liryki powstające w Padwie - znalazły się w Elegiach (dwie pierwsze księgi powstały prawdopodobnie ok. 1559-1561), Lyrica obejmują utwory późniejsze, Foricoenia - łacińskie fraszki - powstawały zarówno w okresie studiów padewskich, jak i w latach późniejszych ${ }^{18}$. Łacińskie juwenilia nieco tylko poprzedzają pierwsze polskojęzyczne utwory poety: poematy Zuzanna (1561), Szachy (1564) i Satyr albo Dziki mąż (1564). Być może pierwsze próby poezji polskojęzycznej podjął Kochanowski już w okresie padewskim. Do wczesnych wierszy należy między innymi hymn o incipicie „Czego chcesz od nas, Panie”, być może powstały już podczas pobytu we Francji pod koniec lat 50 . XVI wieku ${ }^{19}$. W kolejnych dekadach powstały najwybitniejsze dokonania Kochanowskiego: Odpra-

${ }^{16}$ P. Wilczek, Dyskurs - przekład - interpretacja. Literatura staropolska i jej trwanie we wspótczesnej kulturze, Katowice 2001, s. 62-75 s. 62.

${ }^{17} \mathrm{~J}$. Abramowska, Kochanowski, dz. cyt., s.28.

${ }^{18} \mathrm{~J}$. Ziomek, Renesans, Warszawa 1996, s. 256.

${ }^{19} \mathrm{~J}$. Pelc, Jan Kochanowski poeta renesansu, dz. cyt., s. 62. 
wa posłów greckich (1578), Psałterz Dawidów (1579), Treny (1580) oraz pisane przez całe życie fraszki i pieśni, które ukazały się w osobnych tomach w 1584 i 1586 roku.

Kochanowski traktował utwory łacińskie i polskie jako dwa równorzędne nurty w swojej twórczości. Literaturoznawcy podejmowali jednak badania przede wszystkim polskojęzycznych utworów poety, jego łacińskim dokonaniom nie poświęcając zbyt wiele uwagi. Obok rozprawy Alfreda Feia ${ }^{20}$, szkiców Aleksandra Brücknera ${ }^{21}$ i Wiktora Weintrauba ${ }^{22}$, prac Zofii Głombiowskiej $^{23}$ i Alberta Gorzkowskiego ${ }^{24}$ istnieje niewiele opracowań podejmujących problematykę łacińskiej poezji Mistrza z Czarnolasu czy poświęconych stosunkowi obu nurtów językowych, analizie podobieństw, różnic czy zależności ${ }^{25}$.

Łacińskie wiersze Kochanowskiego cieszyły się sporą popularnością wśród polskich padewczyków i były znane przedstawicielom innych nacji, związanym z wybitną uczelnią. Dowodem uznania stało się między innymi powierzenie poecie napisania epitafium dla Kretkowskiego, wyrytego na nagrobku w bazylice świętego Antoniego w Padwie. W ojczyźnie Kochanowski także pragnął zaistnieć jako poeta nowołaciński - autor utworów okolicznościowych o politycznym charakterze, jak na przykład łacińska elegia, opiewająca inflancki triumf Zygmunta Augusta ${ }^{26}$. Powracając do Polski w 1559 roku, Kochanowski był już autorem wielu wierszy łacińskich, w tym niemal ukończonego zbioru elegii Ioannis Cochanovii Elegiarum libri duo. Nie zaprzestał jednak uprawiania nowołacińskiej poezji humanistycznej, w 1569 roku napisał elegię na ingres Filipa Padniewskiego na biskupstwo krakowskie, dedykował odę Henrykowi Walezemu, poematem Gallo crocitanti odpowiedział na paszkwil nadwornego poety zbiegłego króla, w 1580 przygotował do druku tom Lyricorum libellus, a w 1584 - tom zawierający nową redakcję Elegii oraz Foricoenia ${ }^{27}$. Te obszerne zbiory wierszy miały ogromny wpływ na recepcję twórczości Kochanowskiego oraz na sposób, w jaki postrzegali go współcześni. Wcześniej poeta publikował pojedyncze utwory i niewielkie zbiorki poezji, w których podejmował tematykę okolicznościową, przede wszystkim polityczną ${ }^{28}$. Pojęcia państwa i obywatela, w podobny sposób zarysowane w łacińskich i polskich utworach tego okresu, wskazują na spójność politycznych poglądów Kochanowskiego, postrzegającego cnotę i zgodę jako fundament dobrego funkcjonowania społeczeństwa.

W poemacie Zgoda (1564) apelował o jedność narodu, zapewniając, że zgoda to „stróż rzeczypospolitych" (w. 3) ${ }^{29}$, a jej brak rujnuje państwo, udaremnia sprawne funkcjonowanie sądów i osłabia granice ${ }^{30}$.

${ }^{20}$ A. Fei, Kochanowski polski i łaciński, „Pamiętnik Literacki” 1935, R. XXXII, z. 3/4.

${ }^{21}$ A. Brückner, Księga miłości Jana Kochanowskiego, „Pamiętnik Literacki” 1933, R. XXIX.

${ }^{22}$ W. Weintraub, Polski i łaciński Kochanowski: dwa oblicza poety, [w:] tegoż, Rzecz czarnoleska, Warszawa 1977.

${ }^{23}$ Z. Głombiowska, Łacińska i polska muza Jana Kochanowskiego, Warszawa 1988.

${ }^{24} \mathrm{~A}$. Gorzkowski, Bene atque ornate. Twórczość łacińska Jana Kochanowskiego w świetle lektury retorycznej, Kraków 2004.

${ }^{25}$ Stan badań prezentuje Zofia Głombiowska, zob. Łacińska i polska muza..., dz. cyt., s. 5.

${ }^{26} \mathrm{~J}$. Pelc, Jan Kochanowski poeta renesansu, dz. cyt., s. 34.

27Tamże, s. 54, 58, 62.

${ }^{28} \mathrm{~W} 1579$ roku ukazał się Psałterz Dawidów, tom niewątpliwie obszerny, ale postrzegany jako przekład. Z. Głombiowska, Eacińska i polska muza..., dz. cyt., s. 10.

${ }^{29}$ Cytaty dzieł polskich według edycji J. Kochanowski, Dzieła polskie, opr. J. Krzyżanowski, Warszawa 1969.

${ }^{30}$ Z. Głombiowska, Łacińska i polska muza..., dz. cyt., s. 11. 
Niech się miasto otoczy trojakimi wały,

Trojakimi przekopy i mocnymi działy:

Kiedy przyjdzie niezgoda, uniżą się mury

I wnidzie nieprzyjaciel nie szukając dziury.

J. Kochanowski, Zgoda, w. 7-10

Podobne poglądy wyraził w pieśni Ad Concordiam (wydanej w zbiorku Lyricorum libellus, 1580), wysławiając tytułową boginię jako dawczynię organizacji państwowej i opiekunkę istniejących już państw.

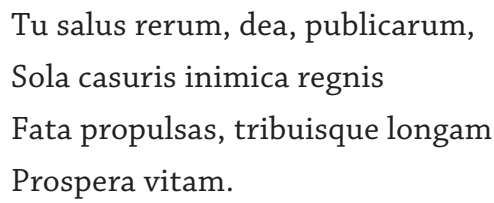

Ad Concordiam, w. 25-28 31

Z kolei w Odzie VI In conventu Varsoviensi (również ze zbioru Lyricorum libellus), podobnie jak w napisanym po polsku Satyrze, poeta zaznaczył, że osiągnięcie zgody w państwie w dużym stopniu zależy od postawy władcy i powiązał tę wartość z pojęciem cnoty. Człowiek cnotliwy potrafi odrzucić afekty, w Satyrze określone jako „mocarki dziwne” (w. 357): nadmierną popędliwość, żądzę, bojaźń, żałość i przesadną radość. Stoicka geneza takiego rozumowania nie pozostawia wątpliwości i daje się zauważyć także w utworach łacińskich, między innymi w elegii skierowanej do Mikołaja Firleja ${ }^{32}$. Tak pojęta definicja cnoty łączy dobro jednostki z dobrem społeczeństwa i państwa. Jak pisze Zofia Głombiowska:

Jednostka nie może osiągnąć doskonałości w oderwaniu od państwa, dobro jednostki [...] powstaje w wyniku działania dla dobra państwa i tylko w taki sposób. Indywiduum zostaje zatem podporządkowane państwu. [...] ta teoria Kochanowskiego istnieje nie tylko w świecie abstrakcji, przeciwnie, jest podstawą oceny konkretnej rzeczywistości polskiej i programu naprawy Rzeczypospolitej ${ }^{33}$.

Tę spójną koncepcję polityczną widać zarówno w polskich, jak i w łacińskich utworach poety, świadomego nieustannie zmieniającej się sytuacji politycznej, uznającego państwo - czyli w praktyce Rzeczpospolitą - za najwyższe wspólne dobro.

Pierwszy obszerniejszy zbiór liryków Elegiarum libri duo, pochodzący z 1562 roku, idąc za wzorami rzymskimi, ukazuje dzieje nieszczęśliwej miłości. Główna bohaterka cyklu, Ligia, najpierw odwzajemnia uczucia bohatera lirycznego, aby później - wiarołomna i zdradziecka - doprowadzić do definitywnego zakończenia romansu. Elementy nawiązujące do rzymskich elegii miłosnych można odnaleźć także w Pieśniach Kochanowskiego, na przykład w Pieśni

\footnotetext{
${ }^{31}$ Cytaty dzieł łacińskich według wydania J. Kochanowski, Dzieła wszystkie, t. 3, Warszawa 1884. Przekład

Z. Głombiowskiej: „Tyś, bogini, ratunkiem rzeczypospolitych, ty jedna odsuwasz nieprzyjazne losy i królestwom bliskim upadku użyczasz łaskawie długiego istnienia". Z. Głombiowska, Łacińska i polska muza..., dz. cyt., s. 217.

${ }^{32}$ Chodzi o Elegię IV 3, por. tamże, s. 217.

${ }^{33}$ Tamże, s. 56.
} 
XI z Ksiąg pierwszych, stanowiącej parafrazę słynnej ody Horacego o dziewczynie, uciekającej przed mężczyzną ${ }^{34}$. W Pieśniach, podobnie jak w Elegiach, liryka miłosna przeplata się z patriotyczną i obywatelską, a podmiot liryczny przyjmuje różne role, jak ulubiony przez poetę Proteus, przybierający postać kochanka, patrioty, cnotliwego obywatela, katolika, poety, epikurejczyka czy stoika.

Kochanowski trafił na studia w Padwie w okresie kształtowania i stabilizacji teorii gatunku literackiego, z jednej strony, mocno zakorzenionego w tradycji, z drugiej - podległego innowacjom epoki ${ }^{35}$. Podjęcie konwencji elegii - dobrze już wówczas ukształtowanej - umożliwiało zatem zobrazowanie teoretycznoliterackich poglądów i wyrażenie stosunku do elegiaca poesis w praktyce twórczej ${ }^{36}$. W twórczości łacińskiej Kochanowski scalił dwa rzymskie modele elegii - Propercjusza i Owidiusza - łącząc liryczny i epicki charakter obu konwencji. Pozwoliło to uwypuklić melancholijną tonację tęsknoty bądź refleksji nad opisywanym obiektem uczuć oraz umożliwiało odniesienie starożytnej łacińskiej frazeologii i leksyki do nowożytnego kontekstu. W elegii polskiej (reprezentowanej przez niektóre liryki ze zbioru Pieśni, np. Pieśń XXI czy Pieśń XXV z Ksiag pierwszych) utrzymanie walorów stylistycznych, wynikających w dużej mierze z metrum, nie było możliwe. W elegiach polskich o zdecydowanie lirycznym charakterze poeta podejmował więc niemal wyłącznie tematykę miłosną, w dwudzielnej kompozycji, ukazując szczęśliwą przeszłość i smutną teraźniejszość bohaterów romansu ${ }^{37}$.

Renesansowa polszczyzna nie potrafiła jeszcze zdobyć się na tak wysublimowane opisy gier miłosnych, jakie Kochanowski zaproponował w zbiorze łacińskich Elegii. Obrazy różnych rodzajów miłości - zmysłowej, czułej, upojnej, pełnej zachwytu czy radości - ukazane zostały w wielu zręcznych porównaniach i metaforach. Na przykład przekładając uroki bliskości $\mathrm{z}$ ukochaną osobą ponad materialne zyski, poeta tak pisał:

Sed licet adverso carpentibus oscula rostro

Indulgere omni tempore coniugio.

Ah, lapis est, lucro quisquis mutavit amorem:

Me socium facit non habet ille sui.

Elegia 4, Księga pierwsza, w. 19-22 ${ }^{38}$

\footnotetext{
${ }^{34}$ Popularność tego motywu w antycznej i staropolskiej liryce miłosnej, żartobliwe przedstawianie kobiecej ucieczki przed mężczyzną oraz ukazywanie ostatecznego zniewolenia ściganej jako elementu wpisanego w harmonijny porządek świata, stanowi dramatyczną przesłankę do rozważań nad akceptowanymi kulturowo sposobami przełamywania erotycznej niechęci (żywionej wobec konkretnego mężczyzny czy całej płci). Świadectwem tej akceptacji jest fakt, że motyw z erotyku Horacego o inc. „Vitas hinuleo misimilis, Chloe” (Carmina I 23), w tłumaczeniu Włodzimierza Tetmajera rozpoczynającego się słowami „Jako sarenka za matką trwożną / Uciekasz, Chloe, przede mną w bór", sparafrazowany przez Jana Kochanowskiego w Pieśni XI z Ksiąg pierwszych („Stronisz przede mną, Neto nietykana, / By więc sarneczka, kiedy obłąkana / Macierze szuka po górach ustronnych, / Nie bez bojaźni i postrachów płonnych") został wykorzystany w barokowej liryce religijnej. W wierszu Macieja Kazimierza Sarbiewskiego bohater liryczny, stęskniony za mistycznym poczuciem zjednoczenia z Chrystusem, mówi „Ty mnie unikasz, Chryste, jak płochliwa / Sarenka leśna...” (Sarbiewski, Lyrica II 17).

${ }^{35}$ T. Michałowska, Poezja i poetyka, Warszawa 1982, s. 99-101.

${ }^{36} \mathrm{~A}$. Gorzkowski, Bene atque ornate..., dz. cyt., s. 81.

${ }^{37}$ Tamże, s. 87.

${ }^{38}$ W tłumaczeniu L. Staffa: „Szczęśliwiej żyje para gołębi zgodliwa, / Których nikt od miłości cichej nie odrywa, / Co dziobkami złączona w pocałunku, może / Małżeńskiego zażywać szczęścia w każdej porze. / kamieniem jest, kto miłość zamienił na zyski, / Nigdy ze mnie towarzysz nie będzie dlań bliski”.
} 
Zupełnie dobrze można było się pokusić natomiast o stworzenie polskojęzycznej liryki biesiadnej, nawiązującej do rodzimej tradycji, u której początków sytuuje się wiersz Przecława Słoty O chlebowym stole. Motywy anakreontyczne, obecne w zbiorach Fraszek i Foricoeniów, przywoływane są jednak inaczej w tekstach łacińskich i polskich, zyskując po łacinie charakter bardziej wyważony i subtelny, po polsku - rubaszny i nie stroniący od języka potocznego. Na przykład we fraszce Do Anakreonta poeta pisze:

Anakreont, zdrajca stary,

Nie masz w swym łotrostwie miary!

Wszystko pijesz, a miłujesz

I mnie przy sobie zepsujesz.

$[\ldots]$

Dobra myśl nigdy bez ciebie.

Do Anakreonta, w. 1-4, 7

Podobny motyw zupełnie inaczej funkcjonuje w foricoenium Ad Philippum Padnevium, w którym o poezji anakreontycznej wspomina się w dużo poważniejszym tonie:

Et nos, Philippe, Theiam

Anacreontis ad lyram

Non invenusta lusimus

Dictante Phoebo carmina.

Ad Philippum Padnevium, w. 5-8 ${ }^{39}$

Albert Gorzkowski, doceniając retoryczne piękno łacińskiej liryki Kochanowskiego, z zachwytem pisze o artyzmie Foricoeniów:

to dzieło retorycznie barwne i rzetelnie dopracowane (eleborata), poświadczające nie tylko znaczny kunszt poetycki autora Odprawy..., ale i świetną znajomość teoretycznych reguł, których praktyczna realizacja znalazła swój miarodajny odpowiednik w dziesiątkach inwencyjnych i elokucyjnych colores, „w kwiatach ogrodu” - by sparafrazować Cyceroniańskie określenie - mowy przejrzystej, zwięzłej i błyskotliwej ${ }^{40}$.

Bilingwizm Kochanowskiego ma charakter funkcjonalny i twórczy ${ }^{41}$. Mistrz z Czarnolasu biegle posługiwał się łaciną - językiem nauki i uniwersytetu, tłumaczył lirykę Horacego, z retorycznym rozmachem tworzył łacińskie foricoenia i elegie, swobodnie poruszając się w ramach gatunku. Dzięki znajomości klasycznych wzorów udało mu się również w polszczyźnie wypracować nowoczesny model uprawiania liryki. Interakcja obu języków i zderzenie dwóch systemów poetyckich ostatecznie zaowocowało tak wieloma innowacjami w polskiej liryce, że

\footnotetext{
${ }^{39}$ Mowa o Foricoenium 38. W przekładzie L. Staffa: „Przy Anakreonta tejskiej / Lirze, Filipie, my sami / Za podszeptem Apollina / bawiliśmy się wierszami”. J. Kochanowski, Z łacińska śpiewa Słowian Muza. Elegie, foricoenia, liryki w przekładzie Leopolda Staffa, Warszawa 1982, s. 161. Interpretacji porównawczej dokonała Z. Głombiowska, Łacińska i polska muza..., dz. cyt., s. 157.

${ }^{40} \mathrm{~A}$. Gorzkowski, Bene atque ornate..., dz. cyt., s. 171.

${ }^{41}$ Por. E. Kraskowska, Dwujęzyczność..., dz. cyt.
} 
zdeterminowało wykształcenie nowego modelu jej uprawiania. Nowe oblicze polskiej poezji, wielowariantowość pierwszego systemu numerycznego, wprowadzenie do polskiej literatury wielu antycznych gatunków i równoczesne przystosowanie poszczególnych konwencji do potrzeb i możliwości polszczyzny, nowoczesna tematyka wyrażana dzięki bogactwu metafor i porównań po części możliwe były właśnie dzięki dwujęzyczności poety. Bilingwizm stał się więc nie tylko fundamentem osobistego progresu Kochanowskiego, ale wzajemne oddziaływanie kultury antycznej i nowołacińskiej na polską myśl humanistyczną wywarło znaczący wpływ na oblicze polskiego renesansu i zadecydowało o rozwoju rodzimej literatury. 


\title{
SEOWA KLUCZOWE:
}

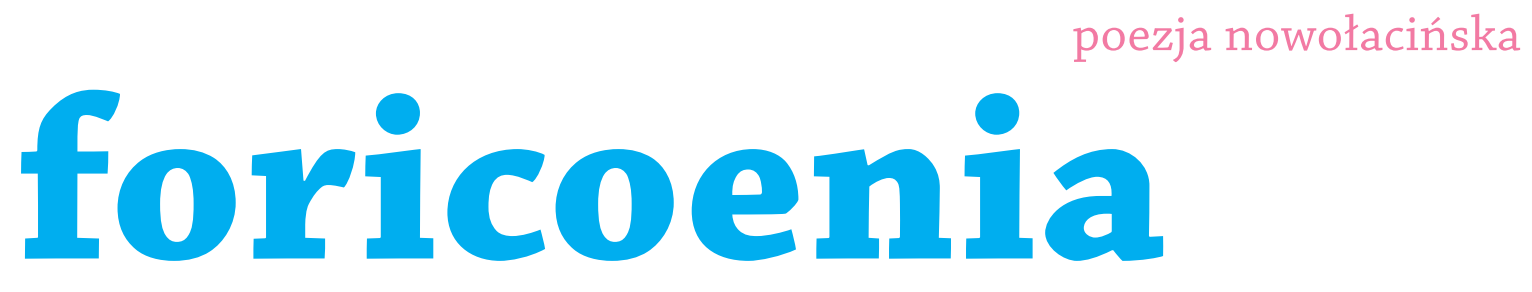

f r a s z k i

\begin{abstract}
AbSTRAKT:
Jan Kochanowski był twórcą dwujęzycznym pisał po łacinie i po polsku. Wybór języka w jego twórczości determinowany jest okolicznościami powstawania utworów (w okresie padewskim tworzy po łacinie, po powrocie do Polski sięga po język ojczysty) oraz tematyka, jaką podejmuje w kolejnych tekstach. Porównanie Foricoeniów i Fraszek czy łacińskich elegii i polskich pieśni pokazuje, że oba języki służą poecie do wyrażania różnych emocji i pozwalają uruchomić inne konwencje literackie.
\end{abstract}




\section{DWUJĘZYCZNOŚĆ}

\section{Kochanowski}

\section{NOTA O AUTORZE:}

Agnieszka Kwiatkowska, dr hab., pracuje w Zakładzie Literatury XX Wieku, Teorii Literatury i Sztuki Przekładu na Uniwersytecie im. Adama Mickiewicza, zajmowała się literaturą i kulturą dawną, opublikowała książkę poświęconą polemiką polskiego oświecenia (Piórowe wojny, Poznań 2001), obecnie bada trwanie i zmienność różnych zjawisk w literaturze oraz twórczość pozostającą na marginesach głównego dyskursu naukowego, m. in. literaturę dziecięcą i poezję kobiet. Jest autorką książki Oświecenie w epokach następnych (Jastrzębie Zdrój 2010) oraz monografii Tradycja, rzecz osobista. Julian Przyboś wobec dziedzictwa poezji (Poznań 2012). 